\title{
O słuchowiskach radiowych „Kukułki Wileńskiej”. Wokół kilku wileńskich rękopisów i maszynopisów Gałczyńskiego
}

Streszczenie: Artykuł omawia słuchowiska radiowe, transmitowane przez radio wileńskie w audycji „Kukułka Wileńska”, których współautorem był Konstanty Ildefons Gałczyński. Poeta przebywający w Wilnie w latach 1933-1936 czynnie uczestniczył w życiu literackim miasta, a szczególnie współpracował z wileńską radiostacją kierowaną wówczas przez Witolda Hulewicza. Twórczość radiowa Gałczyńskiego była obfita. Należały do niej satyryczne wiersze wchodzące w skład większych słuchowisk, skecze i współautorstwo (z Teodorem Bujnickim) radiowych konferansjerek. Omówieniu dwóch konferansjerek, zachowanych w maszynopisach i będących egzemplarzami reżyserskimi, poświęcony jest artykuł. Przede wszystkim uwaga skupia się na ich aspektach humorystycznych, o wyraźnych cechach groteskowej poetyki Gałczyńskiego.

Słowa-klucze: konferansjerka, słuchowisko, humor, groteska, radio, skecz.

Tadeusz Bujnicki - prof. dr hab., prof. em. Uniwersytetu Jagiellońskiego, historyk literatury polskiej. Redaktor i współredaktor wielu tomów, w tym: (z K. Biedrzyckim, J. Fazanem) Żagary. Środowisko kulturowe grupy literackiej (Kraków 2009) oraz (z J. Majchrzyk) Henryk Sienkiewicz w szkole, bibliotece i muzeum (Warszawa 2015). Autor licznych monografii: między innymi Sienkiewicza powieści z lat dawnych: studia (Kraków 1996) oraz Na pograniczach, kresach i poza granicami. Studia (Białystok 2014). 
On radio dramas of "Kukułka Wileńska" [The Vilnius Cuckoo]. On several Vilnius manuscripts and typescripts by Gałczyński

Summary: The article describes radio dramas, broadcast by the Vilnius Radio in the programme "Kukułka Wileńska" [The Vilnius Cuckoo], coauthored by Konstanty Ildefons Gałczyński. The poet, who stayed in Vilnius between 1933 and 1936, actively participated in the literary life of the city, and especially cooperated with the Vilnius radio station at that time headed by Witold Hulewicz. Gałczyński's radio work was abundant. It embraced satirical poems included in larger radio dramas, sketches and radio emceeings prepared in co-authorship with Teodor Bujnicki. The article describes director's cuts of two radio emceeings, preserved as type-scripts. It primarily focuses on their humorous aspects, with clear features of Gałczyński's grotesque poetry.

Key words: radio presentation, radio drama, humour, grotesque, radio, sketch.

O wileńskim okresie w biografii Gałczyńskiego napisano sporo. Wspomnienia Tadeusza Byrskiego ${ }^{1}$, prace Jerzego Stefana Ossowskiego ${ }^{2}$, Tomasza Stępnia $^{3}$, uwagi rozsiane w różnych publikacjach o poecie, tworzą obraz dość szeroki, ale ciągle niekompletny. A prawie trzyletni okres wileński ma istotne znaczenie nie tyle biograficzne, ile twórcze. Co ważne, w Wilnie rozpoczęła się „radiowa przygoda” Gałczyńskiego, ,przygoda” humorysty, który w radiu znalazł właściwe miejsce dla swoich ludycznych eksperymentów. Poeta zaznajomił się tu także ze środowiskiem wspomagającym jego pomysły. Pisał o tym Tadeusz Byrski:

Sprawa humoru w radio [...] był to problem, który od wielu lat spędzał sen z powiek wielu radiowym redaktorom. W Wilnie byliśmy w szczególnie dobrej sy-

1 T. Byrski, Teatr - radio - wspomnienia, Warszawa 1976.

2 J. S. Ossowski, Szarlatanów nikt nie kocha, Kraków 2007.

3 T. Stępień, Gatczyński i media, Katowice 2006. 
tuacji. Objawił się tam znakomity talent satyryczny Teodora Bujnickiego, potem wzmocnił humor w radio przez dwa lata Konstanty Gałczyński. Dużo dobrej satyry potrafili dać z siebie Hulewicz, Łopalewski i Wyszomirski. Czasem i Zagórski, i kilku innych 4 .

Dowody na to znalazły się w moim posiadaniu, dzięki zachowanym archiwaliom radiowym po moim ojcu Teodorze Bujnickim. Są to teksty przeznaczone głównie do cyklicznych audycji „Kukułki Wileńskiej” oraz Klubu Literacko-Artystycznego „Smorgonii”, działającego w Wilnie w latach 1933-19355. „Smorgonia” miała cechy kabaretu literackiego wzorowanego na krakowskim „Zielonym Baloniku”, warszawskim „Picadorze” czy kabarecie „Qui pro quo”. Niemniej humorystyka wileńska i jej mocny związek z radiem posiadały specyficzny charakter. W kształtowaniu różnych form radiowej humorystyki niewątpliwie znaczące role odegrali: ówczesny dyrektor wileńskiego radia Witold Hulewicz oraz wspomniany Tadeusz Byrski.

Odziedziczone przeze mnie rękopisy i maszynopisy (26 pozycji) Gałczyńskiego w roku 2002 przekazałem Muzeum Literatury w Warszawie, zachowując ich skany. Pozostały natomiast w moim posiadaniu teksty niepewnego autorstwa oraz pisane wspólnie z moim ojcem Teodorem Bujnickim konferansjerki radiowych słuchowisk. Im właśnie chciałbym poświęcić nieco uwagi $\mathrm{w}$ niniejszym artykule.

Gałczyński pojawił się w Wilnie już jako twórca uformowany, o własnym stylu i groteskowej wyobraźni. Poeta związany wcześniej z „Kwadrygą”, publikujący w prasie warszawskiej i humorystycznych pismach, takich jak na przykład „Cyrulik Warszawski”, miał już ustaloną pozycję oryginalnego twórcy. $\mathrm{W}$ środowisku wileńskim szybko związał się z radiem i to zapewne dzięki Ta-

4 T. Byrski, Teatr - radio - wspomnienia, dz. cyt., s. 206. Do tego „spisu” należałoby dodać Antoniego Bohdziewicza, Jerzego Putramenta, Stefana Zagórskiego (brata Jerzego) i innych żagarystów (występujących także pod zbiorowym pseudonimem „Arona Pirmasa”).

5 W rocznicę powstania „Smorgonii” pisano w „Zaułku” (dodatek do „Słowa”): „Klub artystyczny w Wilnie pod tą nazwą otwarty został w Wilnie rok temu 1 kwietnia 1933. Od tego czasu odbywają się w »Smorgonii« wieczory dyskusyjne i satyryczne. Pewne programy kabaretu literackiego transmitowane bywają na całą Polskę” („Zaułek” 1934, nr 2). O „Smorgonii” pisałem szerzej w szkicu: Nowi Szubrawcy. Klub Literacko-Artystyczny ", Smorgonia” (1933-1935), [w:] Byle w ludziach światło było. Księga pamiątkowa ku czci profesora Wactawa Woźnowskiego w dziesiąta rocznicę Jego śmierci, red. G. Zając, Kraków 2012, s. 35-49. 
deuszowi Byrskiemu' 6 z którym poznali się w teatrze laboratorium „Reducie” Juliusza Osterwy oraz dzięki Teodorowi Bujnickiemu, z którym przyjacielskie stosunki zostały nawiązane niemal natychmiast ${ }^{7}$. Pierwszą znaczącą próbą radiową był skecz Związek Zawodowy Laureatów pisany wspólnie z Teodorem Bujnickim i Witoldem Hulewiczem już na początku 1934 roku$^{8}$. Kolejnymi efektami „współpracy” z Teodorem Bujnickim były tworzone wspólnie słuchowiska, w których humorystyczne wiersze i skecze łączyła pisana przez obu konferansjerka. Oczywiście powstawały także „osobne” radiowe teksty Gałczyńskiego, jak skecz Cudotwórca z Mejszagoty (transmitowany przez wileńskie radio w marcu 1934 roku) czy Akademia ku czci Bonifacego Magnolii ${ }^{9}$.

W artykule przedmiotem zainteresowania chcę uczynić dwa słuchowiska: jedno, bez tytułu, przygotowane wspólnie z Bujnickim, i drugie zatytułowane Proroctwa wileńskie. W pierwszym wypadku zachował się niemal cały maszynopis konferansjerki (bez strony 3) i wszystkie siedem tekstów Gałczyńskiego ${ }^{10}$ oraz jeden z czterech tekstów Bujnickiego (Kukułka w kajaku). W drugim natomiast - cały tekst konferansjerki z jednym wierszem Gałczyńskiego (Wszystko się chwieje $)^{11}$. W obu słuchowiskach wyraźnie widać dominującą rolę Gałczyńskiego, którego humorystyczny styl i groteskowe sytuacje ogarniają również konferansjerki.

6 Tadeusz Byrski (1906-1987) w latach 1929-1937 był sekretarzem programu Rozgłośni Polskiego Radia w Wilnie, a także jednym z głównych twórców teatru radiowego.

7 Pisał Zagórski: „Bujnicki z Gałczyńskim mieli pokrewne temperamenty artystyczne, dobrze im się układała współpraca, przy której perorowali we wszystkich językach świata znanych sobie i nieznanych. Mieli wyostrzone poczucie muzyki i barwy słowa, ostry dowcip Konstantego był zmiękczany, rozwadniany, uprzystępniany przez świeży humor Dorka. Teksty rosły w terminie, gdyż pod tym jednym względem obaj byli pedantami. [...] Parę lat pobytu Gałczyńskiego w Wilnie uczyniły z nich zgrany tandem [...]”. Zob. J. Zagórski, Tropem Dorka [niedrukowany wstęp do tomu Wierszy wybranych Teodora Bujnickiego (Warszawa 1961). Maszynopis w moim posiadaniu, s. 17].

8 Skecz opublikowany w „Napisie” 2002, seria VIII, z moim komentarzem (s.155-157).

9 Okres „wileński” w twórczości Gałczyńskiego przedstawił w książce Szarlatanów nikt nie kocha Jerzy Stefan Ossowski. Osobny rozdział poświęcony pobytowi poety w Wilnie znalazł się w książce Kiry Gałczyńskiej (Gałczyński, Wrocław 1998: Szczęście w Wilnie, s. 69-95).

10 Ofiara świerzopa (rkps.), Przė̇ycie wycieczkowe (masz.), Cud w winiarni (rkps. i masz.), Muzeum i dziewczyna (rkps. i zapis nutowy), Upadek cioci Lizy (masz.), Śpij, śpij wujaszku - kobysanka (rkps.). Do tego słuchowiska należały także najpewniej dwa teksty Gałczyńskiego: skecz Reportaż ze spływu (masz.) oraz wiersz satyryczny Kajak $i$ kretyn (rkps.).

11 Tytułowe Proroctwa wileńskie są znane z przedruków prasowych. 
Maszynopisy obu konferansjerek są najpewniej egzemplarzami reżyserskimi. Na ich marginesach jest bowiem szereg uwag i dopełnień, a w tekście głównym skreśleń, ręką najpewniej Witolda Hulewicza (sygnatura WH). Są one również przy niektórych tekstach prezentowanych w słuchowisku utworów ${ }^{12}$.

Jedynie w rękopiśmiennych fragmentach zachowało się inne słuchowisko pn. Kompleks wiosenny ${ }^{13}$. Nie ocalała zabawna Kukułka w Bangkoku, z której pozostały tylko maszynopisy wchodzących w jej skład trzech wierszy Gałczyńskiego: Usta dziewcząt z Colombo, W nieruchomym złotym oceanie, Na wielkim okręcie. W maszynopisach i rękopisach znajduje się także szereg - zdeponowanych w warszawskim Muzeum Literatury - przeznaczonych do radia tekstów Gałczyńskiego. Należy jednak podkreślić, że większość swoich „radiowych” wierszy ogłaszał Gałczyński drukiem w wileńskiej i warszawskiej prasie. Natomiast w maszynopisach, aż do pierwodruków w powojennych tomach zbiorowych, pozostawały radiowe skecze. Prawdopodobnie dlatego, iż skecz nie ma struktury gatunku ,czysto” literackiego i w pełni objawia swoją odrębność w prezentacji na radiowej antenie.

„Osobność” gatunku wymaga interpretacji, która uwzględnia specyfikę radiowego wykonania. Skecz jest formą intertekstualną, łączącą teksty literackie z efektami akustycznymi, oddziaływującymi na wyobraźnię słuchacza i wywołującymi wizualne skojarzenia (zasada tzw. „teatru wyobraźni”). Struktura radiowego skeczu zbliża się więc do form dramaturgicznych i mieści się w kontekście tzw. „korespondencji sztuk”. Skecz to z reguły utwór humorystyczny, wyzyskujący ujęcia groteskowe i satyryczne. Współczesne odtworzenie skeczów Gałczyńskiego może być jedynie przybliżoną reprodukcją wileńskich spektakli. Ponieważ na początku lat trzydziestych minionego stulecia nie było zapisów umożliwiających retransmisję słuchowiska, więc miało ono

12 Teksty obu konferansjerek przedrukował w książce pt. Gałczyński i media Tomasz Stępień (Aneks, s. 248-253), jednak bez towarzyszących im tekstów i dopisków reżyserskich.

13 Ręką Gałczyńskiego został zapisany program tej audycji z pierwszą stroną konferansjerki: „I Kompleks wiosenny, II Wiosna w Polsce, III Wskazówki wiosenne, IV Czerwone usta, V Kupleciki wiosenne (wiosna w krąg), VI Ballada staroniemiecka, VII Marionetkarze, VIII Konkurs »Świadomości Literackich«, IX Romanca, X Wiosna w muzyce. Właściwie nie wiadomo dlaczego tyle płaczu, kiedy toną jakieś trzy Polki, no choćby były tak sympatyczne jak te 3 siostry emigrantki. I właśnie w chwili, gdy zbytecznie płaczemy nad dolą tych trzech Polek, perły zagranicznej muzyki toną w pomroku dziejów i odchodzą w niepamięć, gdyby ich raz po raz nie wskrzeszała stara kochana »Smorgonia«. Proszę!” 
realizację jednorazową, niepowtarzalną, dla której zachowane maszynopisy mogą stanowić jedynie ,partyturę”.

Jak pisał Jerzy Zagórski, Bujnicki z Gałczyńskim znaczną część swoich radiowych tekstów tworzyli w Antopruciach na pojezierzu brasławskim, nad jeziorem Pruta, (obecnie Białoruś), majątku Anieli i Konstantego Pisanich, wujostwa żony Bujnickiego. Wspominał Zagórski:

Tego roku [1934 - przyp. T.B.] spędzali lato [w Antopruciach - przyp. T.B.] Gałczyńscy. W przerwach między „pracami” w polu Dorek [Bujnicki - przyp. T.B.] z Konstantym pichcili kolejne teksty Kukułki wileńskiej dla Radia oraz przygotowywali numery dla klubu „Smorgonia” 14 .

Wspólnie także tworzyli konferansjerki do przygotowywanych słuchowisk. Stanowiły one pomysłową ,grę” tekstami wierszy i skeczów, które obudowywali zabawnymi komentarzami, dowcipami i anegdotami. Korzystali zarówno $\mathrm{z}$,kolorytu lokalnego” (jeziorne i rzeczne pejzaże oraz dworkowe przestrzenie), jak i z aktualnych aluzji do zdarzeń i postaci politycznych. Umiejętnie posługiwali się tradycją tej formy, jak i jej unowocześnieniem oraz dostosowaniem do możliwości radiowej realizacji.

Gatunek „konferansjerki radiowej” wywodzi się od dawniejszych sposobów zapowiadania programów w imprezach o charakterze estradowym. Zakłada obecność konferansjera (fr. conférencier), czyli osoby prowadzącej przedstawienie i wprowadzającej poszczególne punkty programu. Zadaniem konferansjera (-ów) było przedstawianie artystów, przygotowywanie publiczności na ich występ, urozmaicanie przedstawień anegdotami i dowcipami. Między konferansjerem a publicznością istnieje „fizyczny”, wzrokowy i akustyczny kontakt.

Słuchowisko radiowe zmienia natomiast „przestrzeń” kontaktu z odbiorcą (słuchaczem), czyni konferansjera i wykonawców „niewidzialnymi”, a więc wymaga modyfikacji środków wyrazu. Słuchowisko należy do szeroko traktowanej twórczości medialnej, nastawionej - jak sama nazwa wskazuje - na słuchanie. Przede wszystkim konferansjer uobecnia się jedynie głosem. W audycji radiowej jest odmianą spikera, o określonym zadaniu nie tylko informacyjnym, ale

14 J. Zagórski, Tropem Dorka, dz. cyt., s. 17. 
i twórczym. Ma tworzyć iluzję czasoprzestrzenną dla wprowadzanych utworów i różnymi sposobami je integrować. Cechą strukturalną konferansjerki jest bowiem łączenie wielotematycznych i wielogatunkowych tekstów, z których część może istnieć samodzielnie (utwory wierszowane, często publikowane w prasie), a część w pełni da się zrealizować radiowo jako skecze. Nieodzownym elementem słuchowiska pozostaje oprawa akustyczna (dźwiękowa). Konferansjer przy tym może mieć nie tylko funkcje „zapowiadacza” programu, lecz także wykonawcy tekstów. W tej roli występował często Gałczyński. Dodać też należy, iż słuchowiska radiowe w międzywojniu kształtują tzw. „teatr wyobraźni”, którego teoretykiem (i realizatorem) był właśnie Witold Hulewicz.

Sama konferansjerka tworzy płynne przejścia między przywoływanymi tekstami a wypowiedziami konferansjera. Ma bowiem nie tylko zapowiadać program, ale go na swój sposób „interpretować”, dopełniać żartem, dowcipem i anegdotą. Nierzadko sama nabiera cech wypowiedzi literackiej, wprowadzając w swój obręb swoiste cytaty. Tworząc przestrzeń „ludyczną”, buduje opozycję śmieszności i „powagi”, wykorzystuje rozmaite style i stereotypy. Słowem, ma charakter wielopoziomowej struktury. Taką formą odznaczają się obie konferansjerki, w których (jak i w całych słuchowiskach) Gałczyński magna pars fuit.

W Antopruciach na pewno powstała audycja „Kukułki Wileńskiej” poświęcona „apologii kajaka”, transmitowana przez radio wileńskie 28 lipca 1934 roku. Konferansjerkę rozpoczyna fraza: „Proszę państwa, dzisiejszy program jest w znacznej mierze pochwałą i apologią kajaka”. De facto apologii kajaka nie było w audycji wiele: w pewnym stopniu w otwierającym ją żartobliwym wierszu Bujnickiego Kukułka w kajaku, ale już skecz Gałczyńskiego Przeżycie wycieczkowe jest raczej wątpliwą apologią, a tym bardziej nie jest nią - Reportaż ze splywu. Za oczywistą drwinę z „kajakowania” należy uznać wiersz Kajak i kretyn. W „składance” różnych tekstów nie tyle „kajak”, ile „wujaszek” - stanowi słowo-klucz. Wujaszków w obręb słuchowiska wprowadza „uczony” wywód konferansjerki, sprowadzający do absurdu rzekome dane rocznika statystycznego:

Stwierdzono statystycznie (Mały rocznik statystyczny na rok 1923, str. 1756 i następne), stwierdzono statystycznie, że co trzeci mężczyzna w Polsce jest wujaszkiem. Pod względem produkcji wujaszków zajmujemy po Danii i Norwegii 
pierwsze miejsce w Europie, a siódme na świecie. Jasne, że nie jest to granica naszych możliwości rozrodczych, mamy nadzieję, że w roku 1936 każdy Polak zostanie wujaszkiem. Ministrowi Poczt i Telegrafów proponujemy hasło na kartki pocztowe: „Nie zamykajmy wujaszków - będzie mniej w więzieniach przestępców”, albo „Wujaszek noszący paczki żywnościowe skraca odległości”.

Wujaszków w słuchowisku jest trzech. Dwóch noszących starożytne imiona: Apollodor i Perykles, oraz bezimienny wujaszek z zamykającej audycję kołysanki Śpij, śpij wujaszku15. Wszyscy „,wykreowani” przez Gałczyńskiego.

Maszynopis konferansjerki i dołączonych do niej tekstów będąc egzemplarzem reżyserskim, dostosowuje się do warunków ,technicznych” radia oraz jest świadectwem intertekstualnej gry zróżnicowanych środków wyrazu, a zwłaszcza tworzy kontekst akustyczny dla całości słuchowiska. Służą mu także „didaskalia” w skeczach, sugerujące odgłosy zewnętrzne wobec wypowiedzi postaci (plusk, bełkot, chrząkanie - Przeżycie wycieczkowe; pauzy - w Upadku cioci Lizy; hałas i ,bardzo skoczny krakowiaczek” w Reportażu ze spływu). Ważnym elementem audycji była też jej oprawa muzyczna. Już niektóre teksty są pisane z myślą o melodii: Muzeum i dziewczyna (,na znaną melodię Moniuszki: tara ram tarata - ta - ta taratata - ta - ta - ram!"’) ${ }^{16}$ i Śpij, śpij wujaszku-kołysanka). Strukturę piosenki ma wiersz Bujnickiego Kukułka w kajaku, a na marginesie maszynopisu Cudu w winiarni znajduje się adnotacja reżyserska: ,Tekst do »Kukułki« na 28/VII. Może zrobisz muzykę?”. Ów meliczny charakter utworów wierszowanych kontrastuje z prozatorsko-dramatyczną strukturą skeczów.

Postać prowadzącego konferansjera (lub dwóch) nie jest w tym słuchowisku klarownie wskazana. Natomiast wyrazisty wydaje się sposób przekazu. Konferansjerka tworzy zabawne ramy dla następujących po sobie tekstów. Sama też stanowi całość ludyczną przez wprowadzanie żartu, anegdoty i parodii - jako elementów konstrukcyjnych i otwierających kolejno przytaczane utwory. Ich pozornie pozbawiona logiki kolejność spełnia zasadniczy wymóg

15 Za prototyp wujaszka z „kołysanki” można uważać gospodarza Antopruć - Konstantego Pisaniego.

16 Reżyser jednak (Witold Hulewicz) proponuje „zrobienie muzyki” Tadeuszowi Szeligowskiemu lub Stanisławowi Węsławskiemu. Zachowana „partytura” do wiersza należy do tego ostatniego. 
audycji: zaskakiwanie i zaciekawianie słuchacza. Dlatego pozostaje w niej mnóstwo chwytów fatycznych obliczonych na reakcje odbiorcze.

Już pierwsza cząstka konferansjerki łączy styl poważnego komentarza $\mathrm{z}$ anegdotami o siedmioletnim Bernardzie Shaw i ślubie barona (uczestniku wojny siedmioletniej) zakończonym katastrofą. Anegdoty te są jednak autonomiczne, obliczone na zaskoczenie słuchacza, co zresztą podkreśla komentarz konferansjera: „To, co opowiedziałem, nie ma jednak żadnego związku z piosenką, która otworzy nasz dzisiejszy program"17.

Kolejne zapowiedzi ściślej wiążą się z utworami. I tak na przykład wprowadzenie wiersza Ofiara świerzopa wylicza wymyślone, groteskowe nazwy przyrodnicze:

Przyroda. Wielkie słowo, ale któż z nas naprawdę zna przyrodę. Któż wie na przykład, co to jest rozwielitka centkowana, pryszczadło cuchnące, frliczka pospolita, albo bulba pedestris? A kto z nas wie, co to jest świerzop?

Podobnie ukształtowana jest zapowiedź Cudu $w$ winiarni. I tu wyliczenie łączy stereotypowe zwroty (,cuda techniki”, „cuda przyrody”, „cuda wyborcze") z absurdalnymi ich dopełnieniami:

Rozmaite bywają cuda. Cuda techniki, na przykład elektryczna maszynka do rozbijania jaj, cuda politechniki - profesor Bartel, cuda przyrody, cuda wyborcze i inne. Odrębną kategorię cudów stanowią cuda w winiarni.

Kolejnym „chwytem” humorystycznym pozostaje wprowadzana w wypowiedź konferansjera parodia ozdobnego, sentymentalnego stylu:

Nasz program ma się ku końcowi. Jest już późna noc. Mrok swoim słodkim weIonem spowił domy i drzewa, księżyc schował się za chmurkę, jest tak cicho, że nawet morderca słyszałby bicie własnego serca. I nam również oczy do snu się kleją, nasze śliczne oczęta. Zanim odejdziemy do swych domów, by spocząć na tachtach pod wzorzystymi baldachimami, pozwalamy sobie przesłać....

17 Ten fragment tekstu jest dopisany ręcznie (nie przez Gałczyńskiego, ani Bujnickiego). Prawdopodobnie - przez Witolda Hulewicza, który sygnował maszynopis. 
W obręb konferansjerki wprowadzają jej autorzy także wierszowane utwory, jak na przykład wsparty na kalamburze czterowiersz:
Polował pan Hubert nad brzegami Rosi
wiadomo, człowiek strzela, Pan Bóg kule nosi.
Przyszedł Grabski i inni. I podatki srogie.
Dziś Hubert nosi kule chodząc z Panem Bogiem.

W tym krótkim czterowierszu, poza ironicznym przekształceniem przysłowia, zawiera się i aluzja polityczna (reformy Grabskiego i „srogie podatki”). Ten chwyt w szczególnym natężeniu powtarza się w zamknięciu konferansjerki, łącząc groteskowy melanż aluzji z życzeniami „...dobrego snu następującym zjawiskom, instytucjom i osobom":

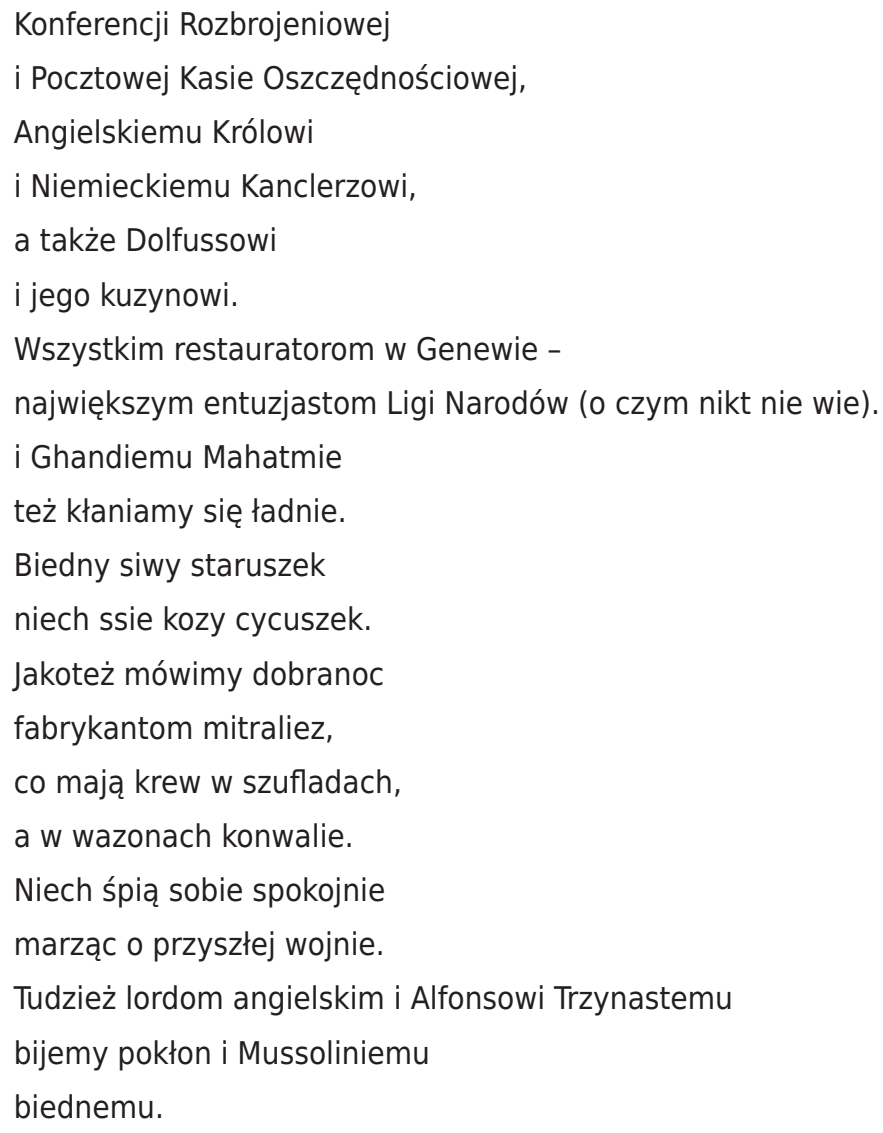


Z Polaków zacnych pana Sławka mamy na oku, niech śpi pod ciepłą kołderką, jak księżyc w obłoku na prawym boku.

Poniatowskiemu życzymy, aby spał miło śniąc, że parceluje Radziwiłłów.

Morzu Polskiemu, aby smacznie szumiało i wszystkim innym, których nie wymieniamy, bo miejsca mało. Śpijcie góry, doliny, [płci] szkoły męskie i żeńskie Dobrej nocy wam życzy kochane Radio Wileńskie.

Treściowo całe słuchowisko wypełniają składniki zarówno lokalne, umieszczane w pejzażu „krainy jezior” i „modrzewiowych dworków”, w środowisku „strasznych" mieszczan i ziemian, jak i „globalne” - wypełniane aluzjami społecznymi i ideologicznymi. Jest rzeczą charakterystyczną, iż szczególnej presji zostaje poddany „świat” urzędniczo-inteligencki, z jego językiem i stereotypami. Konferansjerka tą mozaikową rzeczywistość „porządkuje” i pozornie „racjonalizuje", tworząc w efekcie obrazy groteskowe i purnonsensowe, sprowadzające do absurdu działania postaci i sytuacje, w jakich się one pojawiają.

O ile teksty wprowadzanych do audycji wierszy odpowiadają formule estradowości, recytowane zasadniczo przez jednego wykonawcę, o tyle nowym gatunkiem, dostosowanym do możliwości radia, są skecze. W omawianej audycji pojawiają się trzy - wszystkie pióra Gałczyńskiego (Przeżycie wycieczkowe, Upadek Cioci Lizy oraz Reportaż ze spływu).

Dwa pierwsze mają podobną strukturę i postacie. W obu Gałczyński „gra” stereotypami, które podbarwia ironiczność i satyryczność. Dominuje w nich komizm sytuacyjny. Wydarzenie stanowiące oś miniaturowej akcji w Przeżyciu wycieczkowym to zabłąkanie w „dzikiej głuszy poleskiej” wycieczki kajakowej wuja (Apolldora) z siostrzeńcami Leszkiem i Lunią, natomiast w Upadku cioci Lizy - „wpadnięcie” do studni tytułowej postaci. W pierwszym wypadku turystami są mieszkańcy miasta, którym wyprawa sprawia nieoczekiwane trudności i wyzwala „konflikt pokoleń”. Stereotyp „zacofanego” wujaszka (którego antyczne imię tworzy dodatkową aurę komizmu) zderza się tu z „nowoczesnymi” poglądami jego siostrzeńców. Zarazem ujawnia się absurd sytuacyjny: nieporadność wycieczkowiczów, którzy w poprzedniej wsi zostawili plecak. Dialog odkrywa ów kontrast miejskich przyzwyczajeń i niedostosowania: 
Wujaszek: [...] Wyciągnęliście mnie podstępnie na tę wycieczkę, a teraz nawet jeść nie dajecie i utopić chcieliście.

Lunia: To przecież sam wujaszek chciał z nami jechać, jakbyśmy potrzebowali w wieku XX przyzwoitek.

Wujaszek: Ach, tak. To może wszystkiemu winien stary wuj Apollodor. Wyrodne dzieci. Radźcie sobie same, żegnam was i odchodzę.

Lunia: Wujaszku, gdzie wujaszek idzie. Tam bagna i moczary. Tajemnicza głusz poleska. Noc ciemna.

Leszek: Przecież wuj nie ma spinek i kołnierzyka.

Wujaszek: Ach, prawda, zapomniałem. Jestem więc zmuszony zostać z wami. Dajcie jeść.

Lunia: Przecież nie ma nic do jedzenia, wujaszku. Tyle razy o tym mówimy.

Wujaszek: Młodzież dzisiejsza przenika mnie wstrętem. Jak to? Będąc na łonie przyrody, wśród rzek i jezior nie móc nic znaleźć do jedzenia? A rybki, grzybki, kaczuszki, lilje wodne...

Antagonizm wujaszka i siostrzeńców na tle „dzikiej” przyrody wyzwala kolejne humorystyczne efekty: aluzje do literatury podróżniczej (rozpalanie ogniska przy pomocy tarcia, a nie zapałek - ,wujaszek człowiek dorosły i wierzy w tarcie" - mówi Leszek; przypominany Verne’owski bunt załogi i wysadzenie kapitana na bezludną wyspę) i do Lilli Wenedy Słowackiego (lilie wodne jako pożywienie). Komizm sytuacyjny dopełniają nieporozumienia słowne (,kontra” - jako ruch wiosłem i odzywka brydżowa), odczuwanie przez wycieczkowiczów braku przedmiotów „cywilizacji”: spinki i kołnierzyka wuja, pudru i kremu Nivea Luni, aparatu fotograficznego Leszka. Gałczyński nieustannie „,bawi się” wytworzoną sytuacją - eksponując niedostosowanie mieszczuchów do przyrodniczej przestrzeni i ich zachowania w sytuacji wydawałoby się „ekstremalnej” - zabłąkania w „tajemniczej głuszy poleskiej”. Komiczny finał - przypadkowy powrót do wsi, z której się wypłynęło - kojarzy skecz z wierszem Kajak $i$ kretyn.

Szczególnie znakomitym pomysłem groteskowo-humorystycznym jest drugi skecz: Upadek Cioci Lizy. Już sam „poważny” tytuł stanowi kontrast wobec przedstawionego zdarzenia. „Upadek” może sugerować klęskę, niepowodzenie lub upadek moralny, tu natomiast jest fizycznym ,wpadnięciem” do studni, a więc banalizacją tytułu. Zachowania i wypowiedzi postaci: wuja 
Peryklesa, jego siostrzeńca Gucia oraz Cioci Lizy tworzą cały szereg komicznych spięć wspieranych głównie na „dosłowności” stereotypów. Skecz umieszczony w ziemiańskiej przestrzeni „modrzewiowego dworku”, kształtuje sytuację „obyczajową”, wprowadzając ciągi groteskowych wypowiedzi wujaszka Peryklesa ${ }^{18}$. Odtwarzają się w nich rozmaite obiegowe stereotypy w takim natężeniu, że nieuchronnie prowadzą one do absurdu:

Z tą loterią to musi być jakieś nabieranie. Powiadają, że tam tymi bębnami kręcą sieroty [...]. Ale - czy sierota musi koniecznie być anioł? Życie to nie bajka Andersena. No, sprawdźmy jeszcze raz. - Oczywiście, okulary znowu kot ściągnął... 112-34... 12-34... W głównych wygranych naturalnie nie ma, nie dla psa kiełbasa - na pewno jakiś Żyd wygrał [...]. I znowu 10 złotych fiut. Co za loterie teraz urządzają!

W podobnym duchu są „wychowawcze” wypowiedzi wujaszka Peryklesa skierowane do siostrzeńca Gucia. Reakcją na wiadomość, iż Ciocia Liza wpadła do studni, są uwagi o współczesnych (złych) dzieciach:

...A lekcje odrobiłeś? A ile jest trzy i pół + dwa i pół minus cztery i jedna czwarta... Co? Nie wiesz? Skończysz jak twój ojciec. Byłeś osioł, jesteś stołowa noga, a będziesz baran. Natychmiast marsz z pokoju. Boże, co za dzieci teraz się rodzą.

Groteskową „scenerię” ogrodu i otoczenia wypełniają: fortepian („Sam wujaszek kazał go wynieść. > Jak nikt na nim nie gra. To niech się lepiej zniszczy”) śpiąca ciocia Elwira, która „Wrzeszczy w nocy, gdy się przeje plackami”. Wreszcie studnia, której zabytkowość kontrastuje z sytuacją Cioci Lizy:

To bardzo stara i piękna studnia. Kiedyś ta studnia była na fotografii w miesięczniku „Sztuki Piękne”.

18 Tutaj, podobnie jak w skeczu poprzednim, imię wujaszka pochodzi ze starożytności. Co więcej, tym razem odnosi się ono do historycznej postaci twórcy ateńskiej demokracji, polityka wspierającego rozwój kultury i sztuki - Peryklesa. Gałczyński świadomie trywializuje pierwowzór, wyposażając swoją postać w cechy „strasznego”, zacofanego ziemianina. 
W skeczu znajduje się także jedno większe „wtrącenie” autorskie kierowane wprost do radiosłuchacza:

Cichy modrzewiowy dworek zasypia. Gucio zasnął na lewym boku z rękami pod kołdrą. Śni mu się, że przy stole siedzi zgarbiony i rybę je nożem. Wujaszek Perykles drzemie, marząc o lepszych czasach, gdy wszyscy wygrywali na loterii. Któż jednak pomyśli o biednej cioci Lizie? Ty o niej pomyślisz, dobry radiosłuchaczu. Z właściwą sobie wyobraźnią malujesz sobie straszną ciemność panującą w studni, a na jej dnie ciocię Lizę. I ty wiesz, tylko ty jeden wiesz, bo nie śpisz i słuchasz, że ten ohydny dyszkant, który za chwilę rozedrze powietrze, to będzie właśnie głos biednej cioci Lizy ${ }^{19}$.

W skeczu można odnaleźć cały szereg idiomów należących do tradycyjnego repertuaru: „dźwiganie krzyża” w znaczeniu ciężkich obowiązków, „śliczny zwyczaj nieodpowiadania na pytania”, „odpowiedź ordynarna jak cała twoja rodzina”, „wypadki chodzą po ludziach” - to zwroty charakteryzujące mentalność wuja Peryklesa. Osobne miejsce zajmuje akcja ratunkowa, czy ściślej jej niemożność. Zamiast ratunku Perykles proponuje cioci Lizie lektury dla skrócenia czasu: Wallace'a Zielony tucznik, Hanussena ${ }^{20}$ Szajka Odgryzaczy lub Maksymy La Rochefoucauld. Następnie zaś zastanawia się nad teoretycznymi sposobami ratunku, w konsekwencji - oczekiwanie na pomoc i radę Pawcia. W rezultacie niebezpieczny wypadek Cioci Lizy nabiera cech groteskowych, przekształcających się w grozę nadciągającej burzy. Skecz kończy „,autodemaskujące” zdanie Peryklesa: „Mam nadzieję, że deszcz zaleje studnię do pełna".

Upadek cioci Lizy jest pod wieloma względami prototypem Zielonej Gęsi - „najmniejszego teatru świata”. Zwłaszcza w konstrukcji groteskowego świata przedstawionego, w którym mieszają się motywy obyczajowe, ,grozy” i sensacji.

Reportaż ze splywu - ostatni ze skeczów tego słuchowiska wspiera się na parodii reportażu radiowego - sprawozdania ze spływu kajakowego według

19 W Upadku cioci Lizy niewątpliwie kryje się aluzja do sztuki $W$ małym dworku Stanisława Witkiewicza (Witkacego).

20 Być może jasnowidz Erik Jan Hanussen (1889-1933), tytuł książki - żart Gałczyńskiego. 
określonego schematu. I tu zdarzenie kończy się katastrofą - zderzeniem kajaków i tonięciem uczestników spływu. Reportaż zamyka groteskowy kontrast:

Teraz młodzieniec z czarnymi bakami, wykapany książę Pepi, rzuca się na ratunek i również tonie. Hallo, hallo. Mgła gęstnieje. Wszystko spowite czarnym płaszczem ciemności. Nic nie widzę [dyszy]. Zanim nadejdą bliższe wyjaśnienia, dajemy muzykę lekką. Uwaga: łączymy mikrofon z kawiarnią „Belgia”... [PŁYTA: Bardzo skoczny krakowiaczek].

Słuchowisko, o którym mowa, to w znacznym stopniu twór ręki Gałczyńskiego. Poza tekstami wierszy i skeczów niewątpliwie wpływał on na uformowanie konferansjerki, nacechowanej przez charakterystyczne dla niego stylizacje i odwołania.

Odmienną konstrukcję ma druga zachowana konferansjerka do Proroctw wileńskich. Tu wskazanie na postaci ją prowadzące jest jednoznaczne: „Konferansjerkę prowadzą Mama i Syn-schizofrenik”. Oboje są widzami „widowiska” („o, widzisz podnoszą kurtynę”). W rezultacie ma ona charakter dialogowy, kwestie Mamy i Syna nie tylko spełniają funkcje zapowiadające, ale również kreują szczególny typ zależności: „opiekuńcze” zachowania (i wypowiedzi) Mamy i emocjonalne, bojaźliwe reakcje Syna. W rezultacie sama konferansjerka staje się miniaturowym „dramatem” pokoleniowym. W Proroctwach dominuje kontrast dwóch perspektyw. Mama „tkwi” w „dobrych przedwojennych czasach", Syn zaś reprezentuje rozchwianą i cyniczną osobowość następnego (powojennego) pokolenia. W jego zachowaniach nastrój grozy (reakcja na Proroctwa: „Mamo, ja się boję, mamo, chodźmy do domu”) łączy się z uspakajającym infantylnym i paradoksalnym wierszykiem o szczurku. Natomiast wypowiedzi Mamy ogarnia groteskowy kontrast stylizacji na język „dziecinny” pełen zdrobnień, a zawartą w nich treścią:

Przytul się do mnie, maleńki. Może na wódeczkę pójdziesz? Do takiej malutkiej restauracyjki z czerwoniusim szyldzikiem. Dam ci pieniążek, podasz go dobremu panu w białym fartuszku i powiesz „Wódzi dzidziusiowi”. A wtedy dobry biały pan przyniesie ci na spodeczku kieliszeczek i śledzika i powie „Pij, dziecino, pij, krasnoludku kochany". 
Groteskowa jest także absurdalna opowieść o wujaszku Ewaryście:

Syn: Mamo, a jak będzie ten pożar, czy wujaszek Ewaryst też się spali?

Mama: Co ty mówisz? Czy nie pamiętasz, że wujaszek Ewaryst spalił się jeszcze za dobrych, przedwojennych czasów. A było to rozchwianie tak: Wujaszek Ewaryst należał do takich, co lubieją [tak!] się bawić. Co wieczór chodził do Szumana ${ }^{21}$ i tam z jedną artystką bawił się zapałkami. Oczywiście, skończyło się to źle. Pewnego pięknego poranka kelner kabaretu „Szuman” znajduje go zwęglonego. Artystka tylko cudem uniknęła śmierci.

Syn: Gdyby nie palił, toby się nie spalił.

Mama: Jak możesz tak o wujaszku. Straszne dzieci teraz nastali.

Konferansjerka uwidacznia szczególnie mocno nieustanną grę kontrastami, stylizacjami, purnonsensem i paradoksem. Formuje groteskową wizję rzeczywistości. Hipoteza, iż autorem konferansjerki jest Gałczyński, wydaje się więcej niż prawdopodobna.

Interpretując obie konferansjerki, przede wszystkim miałem na uwadze miejsce i znaczenie w nich Konstantego Ildefonsa Gałczyńskiego, autora i współautora tekstów, a także (prawdopodobnie) wykonawcy i ,scenarzysty”; nie sposób jednak pominąć faktu, iż były one swoistym tworem kolektywnym, efektem współpracy autorów, wykonawców, reżysera i scenarzysty. Sposób, w jaki łączyły się te różne inspiracje, należy jednak do innej pracy, bardziej nastawionej na intertekstualną stronę audycji. I kompetencji badacza kultury.

21 Podrzędna restauracja i kabaret Szumana, który w Wilnie cieszyły się ,złą sławą” jako rodzaj ,tingel-tanglu”. 


\section{Bibliografia}

Bujnicki T., Nowi Szubrawcy. Klub Literacko-Artystyczny "Smorgonia” (1933-1935), [w:] Byle w ludziach światło było. Księga pamiątkowa ku czci profesora Wacława Woźnowskiego w dziesiątą rocznicę Jego śmierci, red. G. Zając, Kraków 2012, S. 35-49.

Bujnicki T., W kręgu „Kukułki" i „Smorgonii”, [w:] Dzieło i życie Konstantego Ildefonsa Gałczyńskiego, red. A. Kulawik, J. S. Ossowski, T. II, Kraków 2005, s. 591-660.

Byrski T., Teatr - radio - wspomnienia, Warszaw 1976.

Gałczyńska K., Gałczyński, Wrocław 1998.

Ossowski J. S., Szarlatanów nikt nie kocha, Kraków 2007.

Stępień T., Gałczyński i media, Katowice 2006. 